\title{
Microbial population assessment during IMO-composting production
}

\author{
Nurul Ain Abu Bakar ${ }^{1,2}$, Nazlina Ibrahim ${ }^{{ }^{*}}$, Mohd. Hariz Abdul Rahman ${ }^{2}$ and Nur Alyani Shakri ${ }^{2}$ \\ ${ }^{1}$ School of Biosciences and Biotechnology, Faculty of Science and Technology, Universiti Kebangsaan Malaysia, 43600 \\ Bangi, Selangor, Malaysia. \\ ${ }^{2}$ Strategic Resources Research Centre, Malaysian Agricultural Research and Development Institute, 43400 Serdang, \\ Selangor, Malaysia. \\ Email: drnazlina@gmail.com
}

Received 21 April 2014; Received in revised form 9 November 2014; Accepted 9 December 2014

\begin{abstract}
Aims: In this study, we investigate the used of IMO produce from cooked rice in rice straw composting. The objective of this study is to identify the effect of composting using IMO and different combination of biowaste on composting of rice straw.

Methodology and results: Different types of treatment were used involving rice straw and goat manure with addition or non-addition of IMO. Composting was done for 30 days in a plastic barrel and was manually turned. Temperature was measured daily while samples were analysed for moisture content, $\mathrm{pH}$ value and electrical conductivity (EC). Temperatures in rice straw compost contains goat manure have higher values up to $43^{\circ} \mathrm{C}$. Rice straw compost with treatment of IMO contain pro-long thermophilic phase compared to treatment without IMO. pH recorded 7.0-8.7 during the process with slight fluctuation due to the microbial activities present. EC showed higher value in rice straw compost with goat manure due to the present of soluble salt in manure. Throughout the composting time, we observed the reduction of moisture value ranging from $43 \%$ to $34 \%$. Microbial succession in compost treated with IMO showed high population with $3.16 \times 10^{9} \mathrm{CFU} / \mathrm{g}$ for mesophilic microorganism during the initial phase and $7.9 \times 10^{8} \mathrm{CFU} / \mathrm{g}$ for thermophilic microorganism.

Conclusion, significance and impact of study: Hence, it can be concluded that the IMO introduce during composting provide higher diversity of microorganisms and could pro-long the thermophilic phase, thus accelerating the process of degradation.
\end{abstract}

Keywords: indigenous microorganisms (IMO), composting, rice straw, goat manure, microbial succession.

\section{INTRODUCTION}

Composting is an aerobic process which involves degradation of organic material by microorganism activities into more stabilized products such as fertilisers or soil amendment. Population of microorganisms during composting indicate the performance and quality of the compost. Reports on microbial community during composting had been published but the results obtain are different with every reports released. This may due to the feedstock differences and the vast variety of composting conditions (i.e., type of raw material, facility design, aeration rate, $\mathrm{pH}, \mathrm{C} / \mathrm{N}$ ration, temperature and moisture content) (Ishii and Takii, 2003). Therefore, monitoring of the microbial succession during composting process may provide important information of compost quality.

In order to achieve maturity of compost, the availability of the right bacteria for composting need to be present and their microbial pathway should be complete. Current composting practice relies on indigenous microorganisms to complete the needed biochemical transformation to achieve a finished or stable product. The increased diversity and activity of these indigenous microorganisms can stimulate decomposition process that is important in composting. In Asian countries, including Korea, deliberate collection and culturing of naturally occurring soil microorganisms has been a common agricultural practice for centuries and application of these cultures to crop soils is believed to minimize the need for applications of inorganic soil amendments (Park and DuPonte, 2008).

Previous study by Liu et al. (2011) has shown that addition of microbiological inoculant in compost is able to facilitate the microbial diversity of the compost and cause rapid maturation. In this study, we used IMO cultured from cooked rice as carbohydrate source for trapping beneficial microorganism at the rhizosphere of banana roots. The IMO were used as an inoculant during composting. The objective of this study is to identify the effect of IMO as an inoculant on composting process. 


\section{MATERIALS AND METHODS}

\section{Preparation of IMO}

Preparation of IMO involves 4 stages. The first stage was to isolate IMO using cooked rice that is placed in a plastic container $(1.8 \mathrm{~m} \times 0.7 \mathrm{~m})$ for about $1 / 3$ full. The container was covered with white paper to protect the rice from rodent or insect that may interfere with it content. The plastic container was then buried in the soil under banana plant and was left for 7 days. After this period, white mycelium and fungi are formed on the rice. During this phase, IMO 1 was obtained Preparation of IMO 2 involves mixing IMO1 with equal volume of brown sugar. This mixture was then transferred to a clean plastic container and was kept protected from sunlight for 7 days to allow mixture to ferment (Park and DuPonte, 2008). The phase of IMO 3 was produced by diluting $10 \mathrm{~g}$ of IMO 2 with 1 litre of distilled water. The mixture was mixed until the solution turns brown. This solution was then poured into 8 $\mathrm{kg}$ of rice bran and mixed well in a plastic container (5.5 $\mathrm{m} \times 2.6 \mathrm{~m}$ ). The containers were covered with plastic and rice straw on top. This mixture was left for microbes to propagate for 5 days. After 5 days, white mycelium can be seen on rice bran. IMO 4 phase proceed by mixing gradually equal volume of soil and rice bran containing microorganisms. This mixture was also covered with plastic and rice straw for 5 days to allow further fermentation process.

\section{Composting experiment}

Small scale composting was performed in plastic bins (3.8 $\mathrm{m} \times 4.7 \mathrm{~m}$ ) for 30 days. The organic starting material used in this study was rice straw and goat manure. Four types of treatment were used in composting:

1) T1: Rice straw only $(2.5 \mathrm{~kg})$

2) T2: Rice straw $(2.5 \mathrm{~kg})+\mathrm{IMO}$

3) T3: Rice straw $(2.5 \mathrm{~kg})+$ Goat manure $(2.5 \mathrm{~kg})+$ Rice bran $(1.5 \mathrm{~kg})$

4) T4: Rice straw $(2.5 \mathrm{~kg})+$ Goat manure $(2.5 \mathrm{~kg})+$ Rice bran $(1.5 \mathrm{~kg})+\mathrm{IMO}$

The composting bins were placed on a raised based to manage leachate resulting from the composting process (Moqsud, 2010) and were covered to prevent from direct sunlight and rain. Aeration was facilitated by the bins design with holes around the bins. The material was turned manually every 5 days. Experiment was done in triplicate. Sampling on composts was scheduled on the installation day (day 0) and every 5 days until day 40. Composting process and IMO were allowed to propagate until the temperature of the compost equalled to ambient temperature after 30 days (Norida Hanim et al., 2012).

\section{Physical and chemical analysis}

Variation of temperature during composting was taken daily using stem thermometer. The reading was equilibrated for $5 \mathrm{~min}$. Measurement of the $\mathrm{pH}(\mathrm{pH}$ Eutech Instrument $\mathrm{pH} 2700)$ and electrical conductivity (EC) (EC
Thermo Electron Corporation Orion 3 Star) were done by adding $10 \mathrm{~g}$ of compost sample in $100 \mathrm{~mL}$ distilled water and were mixed using shaker (Orbit Shaker, Labline, Model: 3591-1) for 30 min (Kutsanedzie et al., 2012). The supernatant was then used to identify $\mathrm{pH}$ and $\mathrm{EC}$.

Moisture content was determined by gravimetric procedure of weighing samples before and after the water is removed (Moqsud, 2010). Each $10 \mathrm{~g}$ samples were kept in the oven at $105{ }^{\circ} \mathrm{C}$ for $24 \mathrm{~h}$. The following equation was used for determining the moisture content of the compost.

Moisture content $(\%)=\frac{\text { wet weight }- \text { dry weight }}{\text { wet weight }} \times 100$ Analyses were done in triplicate.

\section{Microbiological analysis}

The density of culturable microorganisms during composting was determined by the standard dilution plate count technique. Initial compost suspensions were prepared by suspending $5 \mathrm{~g}$ of sample compost in $45 \mathrm{~mL}$ of sterile phosphate sodium buffer $(0.1 \mathrm{M}, \mathrm{pH} 7)$. The suspension weas shaken at $200 \mathrm{rpm}$ for $30 \mathrm{~min}$. Ten-fold dilutions were made in sterile sodium chloride solution $(0.85 \%)$. Culturable aerobic mesophilic and thermophilic bacteria were inoculated on nutrient agar at the temperature of $30{ }^{\circ} \mathrm{C}$ and $50{ }^{\circ} \mathrm{C}$ respectively. Enumeration of fungi was done on Rose Bengal Chloramphenicol agar (RBC) and was incubated at $30^{\circ} \mathrm{C}$ for 5 days. Actinomycetes were quantified on actinomycetes Isolation agar (AIA) and incubated for 5 days at $30{ }^{\circ} \mathrm{C}$. Microbiological analyses were performed in triplicates.

\section{RESULTS AND DISCUSSION}

\section{Abiotic factors}

A change in temperature at various stages of decomposition of different compost treatments was shown in Figure 1. Treatment using goat manure and rice bran showed higher temperature of compost rather than treatment without goat manure and rice bran. Treatment 1 and treatment 2 shows a slight difference in variation of temperature with the highest temperature during thermophilic phase is at the range of $28{ }^{\circ} \mathrm{C}$ to $33{ }^{\circ} \mathrm{C}$. However for treatment 3 and treatment 4 , the highest temperature attained was at the range of $35^{\circ} \mathrm{C}$ to $43^{\circ} \mathrm{C}$. Temperatures recorded are lower than the optimum temperature achieved around $50^{\circ} \mathrm{C}$ to $60^{\circ} \mathrm{C}$ (Ming et al., 2008). This is probably due to the small quantity of compost mixture used in this experiment $(2.5 \mathrm{~kg}$ and 6.5 $\mathrm{kg}$ ). Larger compost mixture could obtain higher temperature as reported by Bustamente et al. (2013) that obtain temperature values higher than $50{ }^{\circ} \mathrm{C}$ with $150 \mathrm{~kg}$ quantity of compost mixture. The first sampling shows rapid rise of compost temperature that contain goat manure and rice bran. This result agrees with Tchegueni et al. (2013) that show rise of temperature in compost pile contains shea-nut cake and goat manure from $32^{\circ} \mathrm{C}$ to 55 


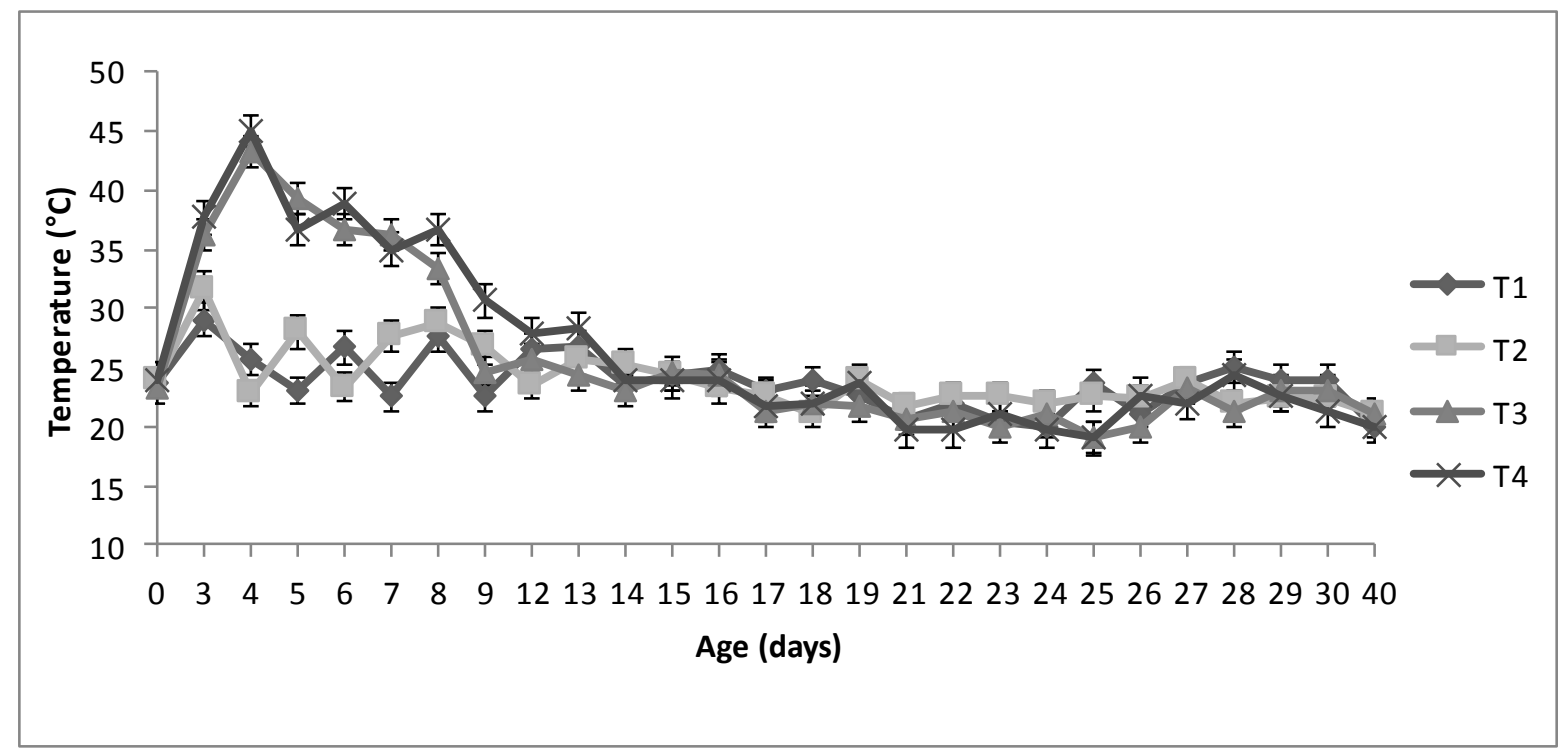

Figure 1: Temperature variation with composting time.

${ }^{\circ} \mathrm{C}$. The used of goat manure in this experiment facilitate the degradation of rice straw composting and improve its fertilizing value and therefore give higher compost temperature. The rise of temperature is due to intense microbial activity that favoured the high concentration of easily decomposable of organic molecules (Tchegueni et al., 2013).

The increase of temperature during day 3 indicates that the composting process is at the thermophilic phase. Although the temperature profiles of IMO-composting were similar to conventional composting, the peak temperature and the rate of temperature increase during thermophilic phase were different. Results obtain shows that treatment in IMO composting have longer thermophilic phase around 7 to 8 days than in treatment without IMO around 3 to 4 days. Based on this various temperature pattern, we assumed that treatment with IMO inoculant have higher microbial activity. Our finding agrees with Jusoh et al. (2013) that shows composting treatment with inoculant effective microoorgnism (EM) have longer thermophilic phase, which is for 6 consecutive days in compared with treatment without EM that only remain for 3 days. The rise and fall of temperature during composting is explained by the turning process done to provide aeration for compost. This was also stated by Ryckeboer et al. (2002) that shows each turning of the barrier content during composting resulted in a temperature increase, but this increase declined as the process succeeded. Compost turning are necessary to reactivate microbial activity by increasing availability of oxygen needed for microorganisms during composting (Cayuela et al., 2006).

Further data on abiotic factors during composting process for each treatment was shown in Table 1. The hydrogen ion concentration $(\mathrm{pH})$ values in each treatment indicate the extent of decomposition within the compost mass. The $\mathrm{pH}$ values recorded in each system was at the range of 7.0-8.7 during the composting process. According to Bernal et al. (2009), a pH of 6.7-9.0 supports microbial growth during composting. Initial phase of composting shows that $\mathrm{pH}$ was at high range with most of the value are at $\mathrm{pH} 8.0$ and above. This result differs from the $\mathrm{pH}$ of composting process reported by Moqsud (2010), where the pH of their composting systems decreases to 6.0 or less during this period. The difference value of $\mathrm{pH}$ may be due to the difference of starting material used for both experiment (Zhu et al., 2007). During thermophilic phase, $\mathrm{pH}$ levels of all compost treatment drops to a minimum level of 7.2-7.0 and gradually increase at the range of 7.7-8.8 during day 10 . At the end of composting, $\mathrm{pH}$ values are at the same point that is 7.5 for treatment 1 and 2 and 7.6 for treatment 3 and treatment 4 . The $\mathrm{pH}$ of the systems throughout the composting process dropped may indicate the activities of microorganisms for ammonification and mineralisation of organic matter (Roca-Perez et al., 2009).

Estimation of soluble salts from compost was determined by electrical conductivity (EC). The results of present soluble salts shows that they were generally low throughout the composting process, with the values at the range of $1.20-2.80 \mathrm{dS} / \mathrm{m}$. Compost treatment using goat manure shows higher trend of EC values compared to the treatment without goat manure. The results obtain are in agreement with manure composting reported by Irshad et al. (2013), that shows increase levels of EC for goat manure composting around $10.4 \mathrm{dS} / \mathrm{m}$ to $10.6 \mathrm{dS} / \mathrm{m}$. Higher EC values in compost involve manure could be cause by the release of salts from manure.

It was observed for moisture analysis that the moisture content of compost gradually decreased with increase in composting age and is at the range of $35 \%$ to $60 \%$ throughout the process (Table 1). Das and Keener (1997) reported when the moisture content exceed $60 \%$, oxygen movement is inhibited and the process tends to 
become anaerobic. Thus, in order to perform proper composting in this experiment, moisture content of composts was set at the optimum level to ensure aerobic condition in the system. The values of moisture content were high in the initial phase at approximately $56 \%$ and decreased to $35 \%$ during curing phase. Reported by
Simujide et al. (2013) showed decreasing of moisture content in sawdust composting from $68.9 \%$ to $45.7 \%$. The decrease of moisture content in some cases may be explained by microbial heat generation causing enhanced desiccation (Tiqua and Tam, 2000).

Table 1: Data of abiotic parameters with composting time for T1: Rice straw only; T2: Rice straw + IMO; T3: Rice straw + goat manure + rice bran; T4: Rice straw + goat manure + rice bran + IMO.

\begin{tabular}{|c|c|c|c|}
\hline Sample* & $\mathrm{pH}$ & $\mathrm{EC}(\mathrm{ms} / \mathrm{cm})$ & $\mathrm{MC}(\%)$ \\
\hline T1-0 & 8.7 & 2.77 & 50.91 \\
\hline $\mathrm{T} 1-5$ & 7.2 & 1.05 & 42.76 \\
\hline $\mathrm{T} 1-10$ & 7.8 & 1.20 & 38.88 \\
\hline $\mathrm{T} 1-15$ & 7.1 & 1.05 & 45.75 \\
\hline T1-20 & 7.4 & 1.27 & 43.28 \\
\hline $\mathrm{T} 1-25$ & 7.3 & 1.37 & 42.40 \\
\hline $\mathrm{T} 1-30$ & 7.6 & 1.93 & 37.08 \\
\hline $\mathrm{T} 1-40$ & 7.5 & 1.85 & 36.95 \\
\hline T2-0 & 8.1 & 1.59 & 55.95 \\
\hline T2-5 & 7.2 & 1.42 & 42.15 \\
\hline T2-10 & 8.8 & 1.42 & 44.86 \\
\hline T2-15 & 7.3 & 1.15 & 44.89 \\
\hline T2-20 & 7.4 & 1.23 & 43.26 \\
\hline T2-25 & 7.4 & 1.23 & 41.88 \\
\hline T2-30 & 7.6 & 1.47 & 42.08 \\
\hline $\mathrm{T} 2-40$ & 7.5 & 1.88 & 41.48 \\
\hline T3-0 & 8.0 & 1.56 & 53.99 \\
\hline T3-5 & 7.1 & 1.68 & 39.93 \\
\hline T3-10 & 7.7 & 1.91 & 38.41 \\
\hline T3-15 & 7.5 & 1.97 & 39.87 \\
\hline T3-20 & 7.7 & 2.17 & 45.18 \\
\hline T3-25 & 7.7 & 1.82 & 42.62 \\
\hline T3-30 & 7.7 & 2.64 & 45.21 \\
\hline T3-40 & 7.6 & 2.75 & 43.26 \\
\hline T4-0 & 8.5 & 2.56 & 52.99 \\
\hline $\mathrm{T} 4-5$ & 7.0 & 1.70 & 40.57 \\
\hline $\mathrm{T} 4-10$ & 7.7 & 1.98 & 37.87 \\
\hline $\mathrm{T} 4-15$ & 7.7 & 1.93 & 45.77 \\
\hline T4-20 & 7.6 & 2.20 & 40.80 \\
\hline T4-25 & 7.7 & 1.75 & 39.65 \\
\hline T4-30 & 7.6 & 2.30 & 37.96 \\
\hline T4-40 & 7.6 & 2.57 & 34.94 \\
\hline
\end{tabular}

*The sample nomenclature follows the $X-Y$ pattern. " $X$ " shows the composting treatment, while "Y" the age (days) of composting process. 


\section{Microbial succession}

The succession of different microbial groups is summarized in Figure 2. Treatment with IMO and without IMO shows difference numbers of microbial community found in the compost systems. The findings suggest that the microbial communities inside the compost system increased by adding IMO to the systems. The initial phase of the composting process showed mesophilic bacteria and actinomycetes were high in number, ranging from $1.0 \times 10^{9}$ to $2.5 \times 10^{9} \mathrm{CFU} / \mathrm{g}$ in all compost treatment. This is due to high availability of nutrients at the beginning of the composting process. Rebollido et al. (2008) reported that substrate during composting was colonized in a major proportion by bacteria, followed by actinomycetes and with a lower number of fungi. However, in comparing between compost treatment using IMO and without IMO, treatment using IMO showed greater colony number of mesophilic bacteria during initial phase of composting. As the process moves toward the thermophilic phase at day 5 , the population of thermophilic bacteria dominated the system that is favoured by the increased of heat. Thermophilic bacteria showed higher numbers in IMOcomposting; T2 and T4 with $5.01 \times 10^{8} \mathrm{CFU} / \mathrm{g}$ and $7.9 \times 10^{8}$ $\mathrm{CFU} / \mathrm{g}$ respectively. The difference number of colony observed in compost treatment with IMO implies addition of IMO was able to improve degradation process by facilitating the microbial diversity present in compost throughout the entire process. Our results agree with the findings by Liu et al. (2011) that suggest bacterial communities in compost changes greatly after mixing with microbiological inoculum.
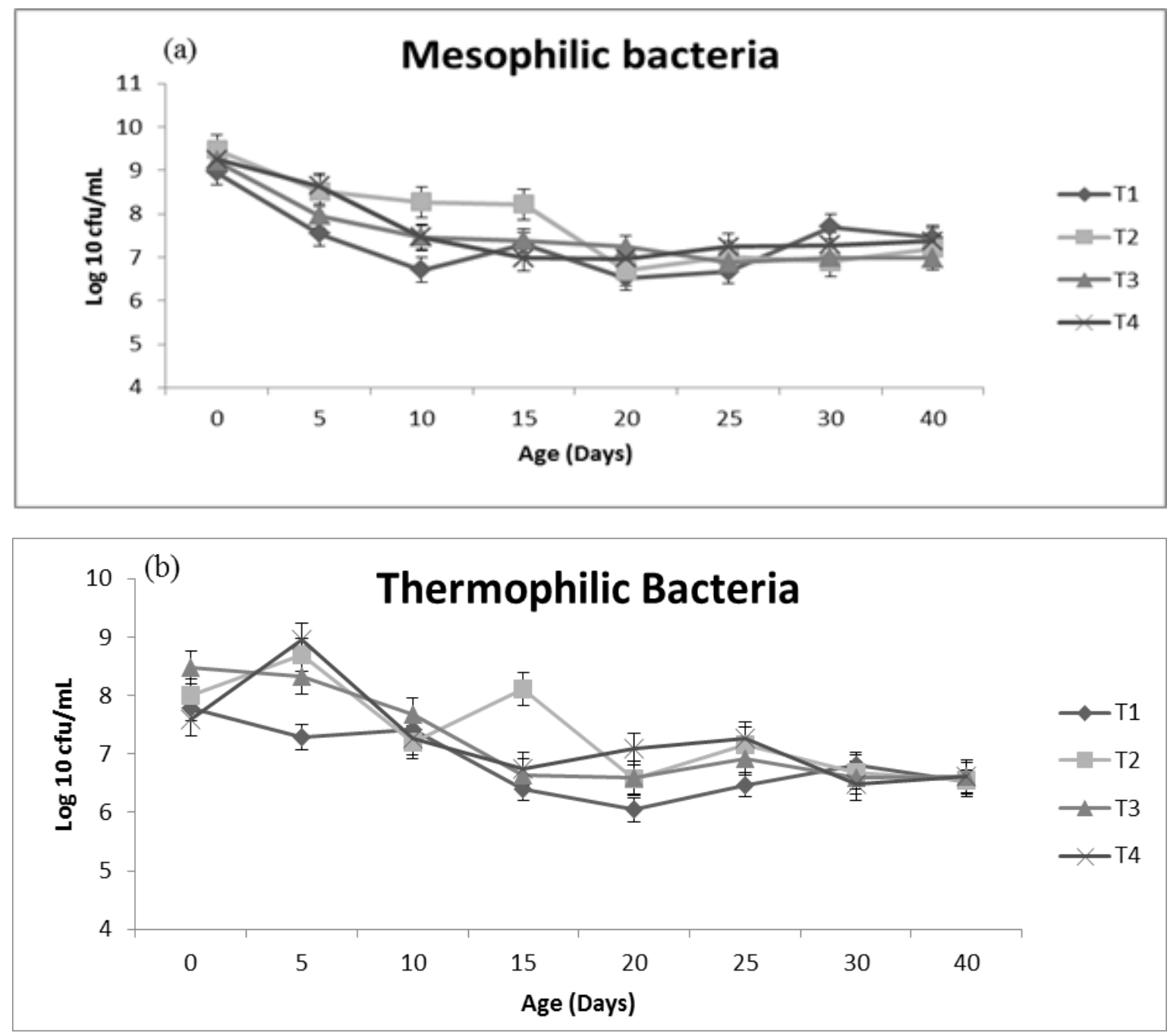

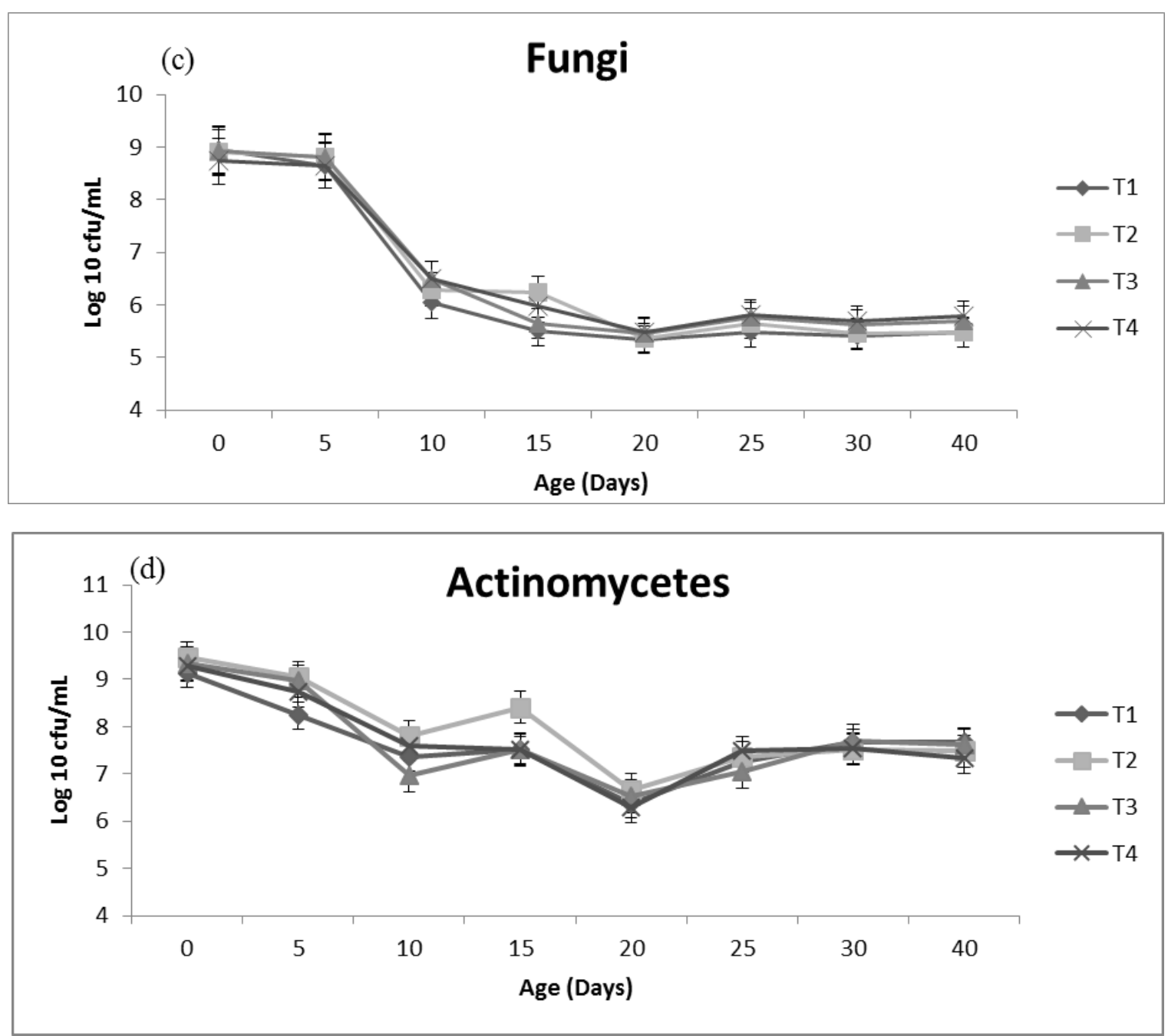

Figure 2: Dynamics of the population of different microbial groups during IMO-composting. a, Total mesophilic bacteria; b, Total thermophilic bacteria; c, Total fungi; $d$, Total actinomycetes.

The microbial succession in this study shows that the fungi population was at the lowest rate after the temperature increase. Population of fungi are much lower in all compost treatment with the the value of $5.01 \times 10^{5}$ $\mathrm{CFU} / \mathrm{g}$ at the end of process in compared to bacteria and actinomycetes species. In earlier studies, Hultman et al. (2009) found that the diversity of fungi is much lower in drum composting than bacteria diversity. Using the cloning based analysis, finding by Hultman et al. (2009) showed similar pattern in our data where the population of fungus decline in the thermophilic phase. Results showed that actinomycetes proliferated when the temperature was low and thermophilic bacteria dominated when it was high. Actinomycetes increased from $1 \times 10^{7} \mathrm{CFU} / \mathrm{g}$ at the end of thermophilic phase to $7.9 \times 10^{8} \mathrm{CFU} / \mathrm{g}$ at day 15 with compost treatment using IMO contain higher number of actinomycetes compared to compost treatment without IMO. Actinomycetes compete with others organisms for nutrients and can inhibit microbial growth due to the production of antibiotics or lytic enzymes. They utilise complex organic compounds and their population tends to increase in the later stages of composting. Simujide et al. (2013) reported that population of actinomycetes in sawdust composting fell initially but then rose during further composting age. Albrecht et al. (2010) observed that actinomycetes and fungi populations drop as temperature increase and actinomycetes became numerous during curing phase of composting.

\section{CONCLUSION}

In general, all parameters measured showed degradation of rice straw throughout time. However, composting without goat manure shows lower degradation rate than composting with goat manure with low temperature obtain during the process. Goat manure facilitated degradation of organic matter, thus allow rapid composting. Results of microbial succession in compost with IMO showed high 
numbers of community bacteria than in compost without IMO. Thermophilic phase in IMO-compost obtain longer time with higher colony of microorganisms compared to compost without IMO. This strongly suggests that compost treatment with IMO aid in composting as the degradation of organic matter occurs mostly during thermophilic phase. Futhermore, treatment with IMO also shows high numbers of microbial community in initial phase and curing phase of composting. Our findings suggest that adding IMO could facilitate the microbial community of the compost by prolonging the thermophilic phase to allow rapid rate of organic matter degradation.

\section{REFERENCES}

Albrecht, R., Perissol, C., Ruaudel, F., Le Petit, J. and Terrom, G. (2010). Functional changes in culturable microbial communities during co-composting process: Carbon source utilization and co-metabolism. Waste Management 30, 764-770.

Bernal, M. P., Alburquerque, J. A. and Moral, R. (2009). Composting of animal manures and chemical criteria for compost maturity assessment. A review. Bioresource Technology 100, 5444-5453.

Bustamante, M. A., Restrepo, A. P., Alburquerquea, J. A., Pérez-Murcia, M. D., Paredes, C., Moral, R. and Bernal, M. P. (2013). Recycling of anaerobic digestates by composting: Effect of the bulking agent used. Journal of Cleaner Production 47, 61-69.

Cayuela, M. L., Sanchez-Monedero, M. A. and Roig, A. (2006). Evaluation of two different aeration systems for composting two-phase olive mill wastes. Process Biochemistry 41(3), 616-623.

Das, K. and Keener, H. M. (1997). Moisture effect on compaction and permeability in composts. Journal Environmental Engineering 123, 275-281.

Hultman, J., Vasara, T., Partanen, P., Kurola, J., Kontro, M. H., Paulin, L., Auvinen, P. and Romantschuk, M. (2009). Determination of fungal succession during municipal solid waste composting using a cloning-based analysis. The Society for Applied Microbiology 108, 472-487.

Irshad, M., Eneji, E., Hussain, Z. and Ashraf, M. (2013). Chemical characterization of fresh and composted livestock manures. Journal of Soil Science and Plant Nutrition 13, 115-121.

Ishii, K. and Takii, S. (2003). Microbial succession during composting process as evaluated by denaturing gradient gel electrophoresis analysis. Journal Applied Microbiology 95,109-119.

Jusoh, M. L. C., Abd Manaf, L. and Abdul Latiff, P. (2013). Composting of rice straw with effective microorganisms (EM) and its influence on compost quality. Iranian Journal of Environmental Health Sciences \& Engineering 10, 17-24.

Kutsanedzie, F., Rockson, G. N. K. and Achio, S. (2012). Comparison of compost maturity, microbial survival and health hazards in two composting systems. Journal of Microbiology, Biotechnology and Food Sciences 2(I), 175-193.
Liu, J., Xu, X. H., Li, H. and Xu, Y. (2011). Effect of microbiological inocula on chemical and physical properties and microbial community of cow manure compost. Biomass and Bioenergy 35, 3233-3439.

Ming, L., Xuya, P., Youcai, Z., Wenchuan, D., Huashuai, C., Guotao, L. and Zhengsong, W. (2008). Microbial inoculum with leachate recirculated cultivation for the enhancement of OFMSW composting. Journal of Hazardous Materials 155, 885891.

Moqsud, A. (2010). Composting barrel for sustainable organic waste management in Bangladesh. Waste Management 29, 1286-1293.

Neher, D. A., Weicht, T. R., Bates, S. T., Leff, J. W. and Fierer, N. (2013). Changes in bacterial and fungal communities across compost recipes, preparation methods, and composting times. PLOS ONE 8(11), e79512.

Norida Hanim, A., Nik, M. M. M., Ahmed, O. H., Susilawati, K. and Khairulmazmi, A. (2012). Physico-chemical properties of indigenous microorganism-composts and humic acid prepared from selected agro-industrial residues. African Journal of Biotechnology 11, 8456-8463.

Park, H. and DuPonte, M. W. (2008). How to cultivate indigenous microorganisms. College of Tropical Agriculture and Human Resources. http://www.ctahr.hawaii.edu/ [Retrieved on 12 May 2014]

Rebollido, R., Martinez, J., Aguilera, Y., Melchor, K., Koerner, I. and Stegmann, R. (2008). Microbial populations during composting process of organic fraction of municipal solid waste. Applied Ecology and Environmental Research 6(3), 61-67.

Roca-Pérez, L., Martínez, C., Marcilla, P. and Boluda, R. (2009). Composting rice straw with sewage sludge and compost effects on the soil-plant system. Chemosphere 75, 781-787.

Ryckebeor, J., Mergaert, J., Coosemans, J., Deprins, K. and Swings, J. (2002). Microbiological aspects of biowaste during composting in a monitored compost bin. Journal of Applied Microbiology 94, 127-137.

Simujide, H., Aorigele, C., Wang, C-J., Lina, M. and Manda, B. (2013). Microbial activities during mesophilic composting of manure and effect of calcium cyanamide addition. International Biodeterioration and Biodegradation 83, 139-144.

Tchegueni, S., Koriko, M., Koledzi, E., Bodjona, M. B., Kili, K. A., Tchangbedji, G., Baba, G. and Hafidi, M. (2013). Physicochemical characterization of organic matter during co-composting of shea-nut cake with goat manure. African Journal of Biotechnology 12, 3466-3471.

Tiqua, S. M. and Tam, N. F. Y. (2000). Co composting of spent pig litter and sludge with forced aeration. Bioresource Technology 72, 1-7.

Zhu, N. (2007). Effect of low $\mathrm{C} / \mathrm{N}$ ratio on aerobic composting of swine manure with rice straw. Bioresource Technology 98, 9-13. 